\title{
Sharing or Limiting the Wealth? \\ Coresidence, Parental Support, and Wealth Outcomes in Canada
}

\author{
August 2018 \\ Forthcoming in the Journal of Family and Economic Issues
}

Michelle Maroto ${ }^{1}$

University of Alberta

\section{Acknowledgements}

This research was partially supported by a Social Sciences and Humanities Research Council (SSHRC) Insight Development Grant (\#430-2014-00092). This analysis is based on Statistics Canada's Survey of Financial Security. All empirical work was conducted at the University of Alberta Research Data Center (RDC).

\footnotetext{
${ }^{1}$ Department of Sociology, University of Alberta, 6-23 Tory Building, Edmonton, AB, Canada,
} T6G 2H4, maroto@ualberta.ca 


\title{
Sharing or Limiting the Wealth? Coresidence, Parental Support, and Wealth Outcomes in Canada
}

\begin{abstract}
This paper examines the relationship between coresidence with adult children, wealth, and economic security using data from the 1999-2012 Canadian Survey of Financial Security (SFS). The results, obtained via propensity score matching and linear regression, show that coresidence with and parental support for adult children is negatively associated with non-home assets and positively associated with debt levels among Canadian households. Further analyses suggest that these relationships stem from differences in financial assets, retirement savings, student loan debt, and credit card balances. By linking theories of economic insecurity, social capital, and life course studies, this study demonstrates how changing trajectories among young adults and financial hardship can influence broader household resources and stability.
\end{abstract}

\section{Keywords}

Life course perspective; Family structure; Emerging adulthood; Family demography; Economic insecurity 
Since the 1980s, rates of coresidence among young adults and their parents have risen across industrialized countries, and especially within Canada, a trend that corresponds with increased life expectancy for adults and a more elongated transition into adulthood for youth (Seltzer and Bianchi 2013). During the same time, young adults, and households in general, have experienced growing economic insecurity with declining safety nets, a tighter labor market, and riskier employment prospects (Banting and Myles 2013; Fortin et al. 2012; Hacker 2006), which has further increased the need for financial transfers within families. This can become especially problematic for parents who continue to support their children into adulthood through coresidence and other types of financial and non-financial transfers (Schoeni and Ross 2005). In such situations, coresidence can function to stabilize resources and act as an investment for a child's future (Bianchi et al. 2007; Swartz 2009), but it can also have destabilizing effects when parents use limited resources to aid children at their own expense (Maroto 2017; Maroto and Aylsworth 2017).

How do changing trajectories for young adults influence parental resources and economic wellbeing? Specifically, what is the relationship between coresidence with and support for adult children and household wealth? To answer these questions, this study analyzed three waves of data from the 1999-2012 Canadian Survey of Financial Security (SFS). First, propensity score matching methods with nearest neighbor matching were used to create balanced samples for families based on the presence of adult children in the household. This helped to reduce selection bias and effect heterogeneity across households by creating treatment and control groups with similar characteristics (Ho et al. 2007; Morgan and Winship 2007; Rosenbaum and Rubin 1983). Doubly robust regression with the same covariates on the matched data was then applied to assess the relationship between the presence of adult children and household non-home assets and debt, two indicators of wealth and economic security that likely fluctuate with household dynamics. To 
supplement these findings, the relationship with financial assets, savings, educational loans, and credit card debt was also examined.

Previous research demonstrates that household structure is related to net worth where two-adult households tend to hold more wealth than others (Lersch 2017; Lupton and Smith 2003; Ozawa and Lee 2006; Zagorsky 2005) and extended household arrangements, most of which contain adult children who receive some support from their parents (Choi 2003; Smits et al. 2010), are often associated with wealth declines (Maroto and Aylsworth 2017). Fewer studies, however, have specifically addressed how continuing parental support for children through an elongated transition into adulthood influences household assets and debt.

This research aims to fill the gap, while also considering the interconnectivity of assets, debt, and financial situations across generations. The framework combines theories of economic insecurity (Hacker et al. 2014; Western et al. 2012), social capital (Bourdieu 1986; Coleman 1988; Portes 1998), and the life course (Elder 1985; Elder et al. 2003) to demonstrate how changing trajectories among young adults influence parental resources and stability. By directly tying individual trajectories to the situations of family members, life course models acknowledge how linked lives are embedded in webs of social obligations characterized by social capital. Because trajectories of parents and children are linked, changes in transitions and economic situations of children have consequences for parents. Although periods of coresidence often improve the economic situations of young adults, support for adult children and continuing coresidence can also strain household resources.

The findings show that coresidence acts as a destabilizing force for household economic security through its negative association with assets and positive association with debt levels. Even after accounting for the household's homeownership status and income, coresidence was associated with an $18.2 \%$ decrease in non-home assets and a doubling of non-home debt. 
Analyses of specific asset and debt variables then build on these results to demonstrate that asset decreases primarily stemmed from financial asset declines, but debt increases were related to educational and credit card debt. The combined asset and debt effects then influenced household balance sheets by pulling total net worth in the negative direction among coresidential families.

Life course theories further acknowledge how individual trajectories are embedded within and shaped by historical time and place, which requires a consideration of broader trends in wealth inequality, economic insecurity, coresidence, and social policy. Although Canada has a stronger welfare system when compared to countries like the United States, funding cuts to social assistance programs and post-secondary education over the past few decades, combined with risker job prospects and few policies that confront wealth disparities, have increased the burdens placed on families (Banting and Myles 2013). To address this context, the paper begins with a discussion of trends in wealth, economic insecurity, coresidence, and support for young adult children in Canada.

\section{Wealth and Economic Insecurity}

Studies of economic insecurity expand on broader inequality research to consider the effects of risks and shocks present in systems of stratification. In this framework, economic insecurity refers to the "degree to which individuals experience and are protected against large economic losses" (Hacker et al. 2014, p. S6) or the "risk of economic loss faced by workers and households as they encounter the unpredictable events of social life" (Western et al. 2012, p. 342). Economic insecurity further entails aspects of resource adequacy and asset sufficiency, factors that affect a household's ability to weather different hardships and survive economic shocks (Hacker et al. 2014). Resources come in many forms that range from government-provided social safety nets to social networks to emergency savings funds and extended assets (Lusardi et al. 
2011; Osberg and Sharpe 2014). Within this framework, wealth, which represents a household's larger stock of resources, becomes central to a family's economic security, especially when other supports are limited (Keister and Moller 2000; Spilerman 2000).

Although wealth provides long-term benefits that include saving for retirement, supplementing education, and supporting entrepreneurship, financial or liquid assets also act as a buffer for economic shocks, allowing families to better manage short-term risks (Lusardi et al. 2011). In addition, despite the current declines in retirement savings that now put younger Canadian cohorts at a higher risk of having inadequate retirement support (MacDonald et al. 2011; Messacar and Morissette 2015), pensions provide an important source of security later in life. Due to their many benefits, assets, which include homes, vehicles, pensions, stocks, and general savings, improve economic security and stability for households.

The relationship between debt, which includes mortgages, balances on credit cards, vehicle debt, education debt, and other types of loans, and economic insecurity, however, is more complicated. Access to credit presents another important economic buffer (Hacker et al. 2014), but higher debt levels can be hard for families to balance, especially when faced with adverse events (Maroto 2015; Sullivan et al. 2000). Thus, there are two wealth factors to consider as measures of economic security -- assets and debt -- especially those types not connected to homeownership, which is harder to access in times of financial hardship. These factors are tied to economic conditions, as well as policy choices and institutional practices at the national and provincial levels (Fortin et al. 2012; Banting and Myles 2013). They also hold implications for household dynamics and changes in the transition to adulthood.

\section{Support for and Coresidence with Adult Children in Canada}

Parental support for and spending on young adult children has increased over time 
(Kornrich and Furstenberg 2013), and parents tend to view their support as integral to children's later success (Settersten and Ray 2010). Coresidence with adult children, in particular, has become more common since the 1980 s with changing life course trajectories among young adults (Bengtson 2001; Milan 2016; Ruggles 2007). In 2011, 59\% of 20-24 year olds and 25\% of 25-29 year olds lived with their parents in Canada (Statistics Canada 2016). Since 1981, this represents increases of $43 \%$ among 20-24 year olds and $123 \%$ among 25-29 year olds. These trends mirror previous U.S. studies, which indicated that that $57 \%$ of 20 - to 22 -year-olds and $25 \%$ of 23 - to 27 year-olds lived with their parents, and $40-50 \%$ of young adults returned home after their initial departures (Aquilino 1996; Yelowitz 2007).

Increases in coresidence coincide with rising economic insecurity that is especially present among young adults, who face lower wages, fewer available jobs, and higher rates of unemployment when compared to earlier cohorts (Milan 2016; Wiemers 2014). In addition to these labor market factors, young adults tend to have greater debt than previous generations, particularly in the form of unsecured debt and student loans (Dwyer et al. 2011; Houle 2014). Housing prices and affordability further influence rates of coresidence, where young adults are less likely to live independently in more expensive areas that include Canada's larger cities (Milan 2016; Yelowitz 2007). As life course trajectories are embedded within time and place, these broader trends factor into the oft cited elongated transition to adulthood.

\section{Linked Lives and Life Course Trajectories}

Most family demographers agree that the transition to adulthood has become longer and more varied with increasing education, housing, and transportation costs since the 1970s and 80s (Furstenberg 2010; Swartz 2008, 2009). In addition to changing trajectories for young adults, this elongated transition also affects parents, particularly those who support their children into 
adulthood (Kornrich and Furstenberg 2013). These relationships reflect the linked lives principle, a key component of life course theory (Elder 1985). According to this principle, "lives are lived interdependently and socio-historical influences are expressed through this network of shared relationships" (Elder et al. 2003, p. 13). The strong intergenerational ties between parents and children and the obligations embedded within their networks become especially relevant when considering how parents support children (Furstenberg 2005).

Parental support comes in many forms that include material assistance through the transfer of money, goods, and housing (Schoeni and Ross 2005; Seltzer and Bianchi 2013; Swartz 2009), payment for schooling (Rauscher 2016), and childcare (Folbre 2012). The amount and type of assistance provided also differs across families (Schoeni and Ross 2005). Parents with higher incomes and education are more likely to provide financial transfers to children (Fingerman et al. 2015), but shared housing is more common among low-income and racial minority families (Seltzer and Bianchi 2013). Even though support varies with the needs and circumstances of the children (Fingerman et al. 2009; Smits et al. 2010), most youth receive some assistance (Goldscheider et al. 2001; Yelowitz 2007) with one-third to one-half of adult youth living independently reporting financial support from their parents (Schoeni and Ross 2005; Swartz et al. 2011).

Overall, households and families are central to understanding aspects of wealth and economic insecurity, which depend on social context, intra-household relationships, and individual circumstances (Macmillan and Copher 2005). Although many studies have used this framework to assess how parental situations affect children, fewer have studied how financial hardship and economic insecurity among children might influence parental wellbeing (Kalmijn and De Graff 2012). Nevertheless, changes in household structure, such as the decision to double up with kin, can have both stabilizing and destabilizing effects on family resources (Cancian and 
Haskins 2014; Maroto and Aylsworth 2017; McLanahan and Percheski 2008). With increasing rates of coresidence, rising debt levels, and growing economic insecurity among youth, this raises the question of what effects might coresidence have on household wealth?

\section{Stabilizing and Destabilizing Effects of Coresidence}

Two perspectives regarding the potential effects of coresidence on assets and debt emerge from the literature. First, coresidence could benefit household wealth through the sharing of resources and provision of economies of scale. By pooling resources, coresidence offers certain benefits, especially for more vulnerable groups that include single parents, young adults, and racial minorities (Glick and Van Hook 2002; Seltzer and Bianchi 2013; Swartz et al. 2011). For instance, Pilkauskas et al. (2014) estimated that doubling up saved urban mothers with young children $\$ 4,000-\$ 5,000$ USD in rent per year or approximately one-quarter of their yearly earnings.

Importantly, coresidence and asset sharing can also act as investments into a child's further success. In Sandberg-Thoma et al.'s (2015) study, children with higher levels of education took longer to leave their parental homes but were less likely to return after moving out. Extended coresidence among these households helped to provide youth with additional resources that improved their later financial situations. In addition to functioning as an investment in a child's future, higher rates of coresidence, especially among racial minority and immigrant families, also stem from cultural preferences (Albertini and Kohli 2013; Hardie and Seltzer 2016; Kamo 2000; Lei and Scott 2016). In these situations, coresidence is a more normative occurrence that does not necessarily lead to economic insecurity.

Although economies of scale provide resources for some family members, research on intergenerational transfers, social capital, and parental spending supports a second perspective, 
which presents a more pessimistic outcome related to the costs of raising children. As expounded by theories of social capital, individuals are embedded in systems of normative obligations, which provide social and financial support for members (Bourdieu 1986; Coleman 1988; Portes 1998). However, because family members often bring different levels of resources into relationships, social capital can have both positive and negative effects (Portes 1998). In the case of coresidence, adult children are able to draw on familial norms of trust and exchange within their networks to improve their situations, but parents also make sacrifices to support their adult children that can have lasting consequences (Furstenberg 2005; Kahn et al. 2013).

To summarize, previous research has shown that parental resources offer important benefits to adult children, but extending resources, such as housing, can also hold negative consequences for parents. Parents' lives are linked to those of their children, which is increasingly obvious through the support provided for adult children, the consequences of which are likely to be reflected in household assets and debt. By examining these variables, this study expands on previous research to assess how coresidence with and support for adult children might influence household economic security. In doing so, this research contributes to literature on family relationships, life course studies, economic security, and wealth inequality more broadly.

\section{Present Study}

How are coresidence with and support for adult children associated with family assets, debt levels, and economic security? And, can the relationship be explained by factors such as family income, homeownership, and household size? In relation to the previous literature, I expect that households who reside with adult children will have lower assets than other households net of key demographic and employment characteristics (Hypothesis 1) for several reasons. First, coresidence is more common among disadvantaged households (Swartz 2009; Weimers 2014), 
and parents with fewer resources more often offer housing as a means of financial support to children (Fingerman et al. 2015). Norms regarding nuclear family households and preferences for independent living also make coresidence a last resort for the most economically disadvantaged adult children (Amato et al. 2007; Fingerman et al. 2015). It follows that households with fewer assets will also be more likely to reside with their adult children.

Second, coresidence and general support for adult children should lead to decreases in parental assets over time as they share resources (Settersten and Ray 2010; Swartz et al. 2011). Although wealth transfers to adult children are a normative occurrence, supporting children into adulthood is expensive, regardless of where children live (Kornrich and Furstenberg 2013), and it can be especially costly for youth who live at home. For instance, Schoeni and Ross (2005) estimated that the average family spent approximately $\$ 4,500$ to $\$ 5,000$ USD per year supporting youth between the ages of 18 to 34 who lived at home. Among those living independently, family support averaged between only $\$ 1,000$ and $\$ 1,700$ USD per year.

In the area of debt, I expect that households who reside with adult children will have greater non-home debt than other households net of key demographic and employment characteristics (Hypothesis 2). Many families take on debt to make ends meet (Sullivan et al. 2000) and parents may secure loans to support their children's development and education (Cha et al. 2005). In addition, total household debt also likely increases with the debt of the adult child. Young adults today are more indebted than previous generations and a larger proportion of this debt comes from student loans and non-secured debt (Dwyer et al. 2011; Houle 2014). These trends, which coincide with increased parental support and coresidence, have also accelerated in recent years as a result of the 2008 recession, at least according to research conducted in the United States (Fry and Passel 2014; South and Lei 2015). 
Together, the expected debt and asset effects have the potential to increase economic insecurity within households when adult children rely on parents for support and continue to live at home (Swartz et al. 2011). Even though coresidence can improve economic wellbeing for certain members, particularly household guests, it is likely in this situation, where norms dictate that parents will provide more support to children than they receive, that coresidential households will be less stable than other living situations. This should become apparent in the relationship between coresidence, assets, and debt.

\section{Data}

In order to cover multiple time periods, I tested these relationships using pooled data from the 1999, 2005, and 2012 waves of the Canadian Survey of Financial Security, conducted by Statistics Canada. The SFS is a reoccurring cross-national survey focused on net worth, debt, and assets. The survey incorporates a stratified multi-stage dual frame design constructed from the Canadian Labor Force Survey (LFS) and the urban portion of the T1 family file (Statistics Canada 2015). To account for this sampling design, all analyses applied the survey-provided integrated household weights. Weights were adjusted for non-response and calibrated to known population totals based on Canadian Census data.

Although the SFS appears to underestimate financial assets and consumer debt, which is likely due to the complexity of wealth and the difficulty many respondents have in estimating their assets and debt (Spilerman 2000), the survey includes some of the best wealth data available in Canada, along with important data on household structure. To address potential data issues, the survey combined responses with information from T1 income tax files and used hotdeck and nearest neighbor matching imputation procedures to account for any additional missing data. The survey also computed totals from detailed debt and asset variables, which improved the reliability 
of estimates.

The SFS uses the economic family household, comprising a group of related individuals living at the same address, as the unit of analysis. ${ }^{2}$ In household-level studies researchers often have trouble differentiating between household guests and hosts (Cohen and Casper 2002; Steele et al. 2013). In these relationships, hosts have greater resources and more independence than guests, who do not have homes of their own (Cohen and Casper 2002). Because the primary respondent in a given household is the economically dominant single individual or the financially most knowledgeable member of the economically dominant couple, I assumed that the respondent was the host with whom the adult child was living. After restricting the sample to primary respondents age 18 and older, a sample of 33,201 households remained. ${ }^{3}$

\section{Measures}

The two primary outcome variables - logged total non-home assets and logged total nonhome debt -- provide complementary measures of the household wealth situation. Following Hacker et al. (2014), I excluded housing wealth as a measure of economic security because home equity is hard for families to easily access and does not fluctuate as much each year. ${ }^{4}$ This also helped to make the results more generalizable to families in different contexts where total wealth was less driven by the housing market. Total non-home assets include savings, stocks, bonds, accessible pensions, and other types of liquid and illiquid assets. Total non-home debt includes outstanding balances on credit cards, lines of credit, vehicle debt, education debt, traditional consumer credit, and other types of loans. All monetary values were adjusted for inflation and

\footnotetext{
${ }^{2}$ Because Statistics Canada only includes related individuals within the household for its definition of an economic family unit, I am referring to family households when discussing families or households.

${ }^{3}$ Missing data were limited due to the survey's use of imputation. Please see Statistics Canada (2015) for more detail on the SFS imputation procedures.

${ }^{4}$ Supplemental models for measures that include home equity and mortgage debt are available upon request.
} 
appear in 2012 Canadian dollars. I also logged these variables to account for skewness.

The secondary outcome variables assess the relationship between coresidence with ten asset and debt components -- any financial assets present in stocks, savings, pensions, and other accounts; logged total financial assets; any savings present in checking and savings accounts; logged total savings; any pensions; logged total pension value; any credit card debt; logged total credit card debt; any educational loan debt; and logged total educational loan debt. Analyzing these variables disaggregated the components behind household assets and debt, which allowed me to determine which specific asset and debt types influence economic insecurity the most.

The primary predictor variable measures the presence of adult children over age 18 in the household. It includes biological and adopted children of the respondent or the respondent's partner. I constructed this variable using information on the age and status of household members and the respondent's relationship to these household members. As shown in Table 1, mean nonhome assets for households between 1999-2012 were \$337,900, mean financial assets were $\$ 56,700$, and mean savings were $\$ 10,800$. Mean non-home debt was $\$ 25,700$, mean credit card debt was $\$ 1,900$, and mean education debt was $\$ 1,800 .^{5}$ These values tended to be lower because they included households who reported no debt or assets. In addition, although approximately 42.3\% of young adults aged 20-29 lived with their parents in 2011 (Statistics Canada 2016), $15.5 \%$ of households reported adult children over 18 as present. The average household size was 2.4 persons with $28.4 \%$ of households reporting children under 18 present and $60.2 \%$ with two adult partners.

\section{[Table 1]}

\footnotetext{
${ }^{5}$ All values are in 2012 \$CAD.
} 
Coresidence, assets, and debt also vary with demographics, disadvantaged group membership, employment circumstances, and credit market access (Spilerman 2000). I therefore controlled for these factors to account for different explanations of family and wealth inequality. To address how wealth varies according to life-cycle models (Lafrance and La Rochelle-Côté 2012; Keister and Moller 2000), models controlled for the respondent's age, along with a quadratic age-squared term to account for non-linearity in this relationship. They also included factors related to marital status and family size, which have been shown to influence wealth (Grinstein-Weiss et al. 2008; Lupton and Smith 2003; Zagorsky 2005), as well as coresidence (Swartz 2009). The first of these measures was household size or the number of people in the family household, which also accounted for the presence of other extended relatives. Models also controlled for whether any children under 18 were present in the household, and household type, which included categories of two adult partners (referent), single male adult, and single female adult. $^{6}$

Because wealth and coresidence vary with disadvantaged group membership (Brzozowski et al. 2009; Glick and Van Hook 2002; Maroto 2016; Maroto and Aylsworth 2016), the models controlled for immigrant and disability status. I included a variable that indicates whether the respondent or the respondent's spouse became a landed immigrant to Canada as an adult and incorporated a measure for whether the respondent, the respondent's spouse, or a child within the household reported a disability. In addition to demographic factors, education and income have generally shown a positive association with asset and debt accumulation across studies (Semyonov and Lewin-Epstein 2013). Education is also related to economic security, higher rates of marriage, and lower rates of multigenerational living (Cancian and Haskins 2014; Kalmijn 2013). Education was accounted for with a variable the indicates whether the primary respondent

\footnotetext{
${ }^{6}$ Partners include married or cohabitating couples and spouses.
} 
obtained a high school diploma (referent); less than a high school diploma; some college, a university or Bachelor's degree; or advanced education beyond a BA. As measures of the household labor market situation, models controlled for logged total household wage and salary income and whether the respondent or spouse was employed.

The models also included a series of control variables to account for credit market access, standing, and behavior. I incorporated categorical variables that indicate whether household members owned their home or had a monthly budget and controlled for whether members of the household provided financial assistance to individuals living outside the household. In addition to being associated with credit market standing and income, this variable also helped to account for potential assistance provided to adult children living outside the home.

Because wealth levels and rates of coresidence vary across Canada (Milan 2016), I accounted for region of the country and size of the area of residence. Region includes the five major regions of Canada -- Atlantic, Quebec, Ontario, Prairies, and British Columbia. Area of residence included three Census Agglomeration (CA) and two Census Metropolitan Area (CMA) categories ranging from rural to populations greater that 500,000. Finally, an indicator for survey year $(1999,2005$, or 2012) was included in all models to account for change over time. The analyses therefore incorporated controls related to key explanations for wealth inequality and varying household structures.

As shown in Table 1, 17.4\% of households contained individuals who immigrated to Canada as adults and $20.4 \%$ reported a disability. Approximately $21.5 \%$ of respondents held a Bachelor's degree or higher in the sample. Nationally, $25.9 \%$ of the population reported earning at least a university degree in 2011 (Statistics Canada 2013). Average employment income across households was $\$ 58,800$, and $73 \%$ of households had a least one employed member. Income levels were close to those reported for the average after-tax income of Canadian households 
between 1999 and 2012, which was approximately \$60,000 (Statistics Canada 2017). Similar to other credit market variables, $61.7 \%$ of households owned their homes and $47.3 \%$ organized monthly budgets. Finally, $49.2 \%$ of households resided in urban areas with a population greater that 500,000, and $37.1 \%$ lived in Ontario.

\section{Methods}

In order to reduce bias caused by treatment selection and effect heterogeneity, I combined propensity score matching methods with regression models to study the relationship between the presence of adult children in a household and a family's logged non-home assets and debt. Propensity score analysis techniques use observational data to create treatment and control groups with similar characteristics based on propensity scores that reflect the estimated probability of receiving treatment (i.e., coresidence) given a set of covariates (Morgan and Winship 2007; Rosenbaum and Rubin 1983). Combining these techniques with regression models, then allows for the better assessment of the direct relationship between coresidence and wealth across matched samples.

In constructing these models, I first estimated propensity scores, which range from 0 to 1 based on the probability of having adult children present in the household, using a logit model with all key covariates described in the measures section. I then used 1:1 nearest neighbor matching to construct a matched sample of family households with and without adult children present. ${ }^{7}$ Nearest neighbor matching uses propensity scores to match each household with adult children to a similar household without adult children present (Ho et al. 2011). This process pairs the observed outcome of a household in the treatment group with the outcome of the "nearest" household in the control group. The models help to ensure balance on observed covariates across

\footnotetext{
${ }^{7}$ Results were also robust to 2:1 and 3:1 matching ratios.
} 
matched samples. The final matched sample included a treatment group 5,022 households with adult children present and a control group of 5,022 households without adult children present. ${ }^{8}$

After creating matched samples of households with and without adult children present, I then applied regression models to the matched datasets using all covariates from the matching models. Logit models were used for the binary outcomes of any financial assets, accounts, pensions, credit card debt, and education debt. Linear regression models were used for continuous outcomes of logged non-home assets, non-home debt, total financial assets, account value, pensions, credit card debt, and education debt. This resulted in "doubly robust regression," where inferences will be statistically consistent if either the matching model or the regression model is correct (Ho et al. 2011). As suggested by DuGoff et al. (2014) and Zanutto (2015), the sample weight variables were incorporated as predictors in the matching equations and then conducted the regression analyses on the weighted matched datasets. Regression models also accounted for clustering in the standard errors through sandwich estimators.

\section{Results}

The results support a situation where coresidence and support for adult children had a destabilizing (or at very least a non-stabilizing) effect on household economic security. Households with adult children present had lower assets and increased debt compared to those without adult children present. This relationship held within doubly robust regression models and net of demographic, employment, and credit market controls. Additional analyses show that many of these relationships also stemmed from specific types of assets and debt, especially financial assets and student loans.

\footnotetext{
${ }^{8}$ Results of model diagnostics and balance statistics for the matched samples are available upon request.
} 


\section{Non-home Assets and Debt}

Table 2 presents the results from regressions on non-home assets and debt using the matched-sample data for families with and without adult children present in the household. Model 1 provides results for logged non-home assets and Model 2 provides results for logged non-home debt. All models control for demographic, employment, and educational factors, along with key credit market control variables.

\section{[Table 2]}

As expected by the Hypothesis 1, households with adult children present held less in assets than those without adult children present, net of household demographics, education, and income. According to Model 1, households with adult children present held approximately $18.2 \%$ less in non-home assets than households without adult children. ${ }^{9}$ Model 2 shows that these disparities were also present in relation to household debt, which provides support for Hypothesis 2. Within Canada, households with adult children present held twice as much debt as otherwise similar households without adult children present. According to these models, it appears as though the debt effects of coresidence were larger than the asset effects. ${ }^{10}$

The models also included a host of control variables to help account for alternative explanations of wealth inequality. ${ }^{11}$ Among these variables, which are also already controlled for through the creation of matched samples, age, income, education, and credit market variables presented some of the strongest relationships with assets and debt. For instance, a one percent

\footnotetext{
${ }^{9}$ Because many of these coefficients exceed 0.1 , I use the following formula to determine the percent change in net worth for a one-unit change in each predictor variable: $\% \Delta(\mathrm{y})=100 *\left(\mathrm{e}^{\mathrm{b}}-1\right)$ (Wooldridge, 2009).

${ }^{10}$ Models were robust to different specifications of assets and debt that included home equity and mortgages.

${ }^{11}$ Because these models are based on the matched sample data, they are not generalizable to the broader population. Results based on the full sample are available upon request
} 
increase in income was associated with a $9.6 \%$ increase in assets and a $10.0 \%$ increase in debt. Homeownership was also an important factor for both outcomes; homeowners held 4 times the assets and 3 times as much debt as non-homeowners. Household size was also significantly associated with debt and assets. Interestingly, net of other factors, each of the education categories presented a significant association with assets but not debt. Among potentially disadvantaged groups, immigrant households held $45.7 \%$ less in assets and $52.3 \%$ less in debt than nonimmigrant households. The presence of a disability was also negatively associated with assets but positively associated with debt. Finally, households that provided assistance to individuals living elsewhere held $34.6 \%$ more in assets and $53.1 \%$ more in debt than households not providing assistance.

\section{Specific Asset and Debt Types}

As a supplement to these models, Tables 3 and 4 assess the relationship between coresidence and a set of more specific asset and debt variables. Table 3 presents results from models estimating the relationship between coresidence and the presence of any financial assets that include stocks, savings, pensions, and other accounts (Model 1), logged total financial assets (Model 2), any checking or savings accounts (Model 3), logged total value of funds in checking or savings accounts (Model 4), any pensions (Model 5), and logged total pension value (Model 6). Table 4 presents results from models estimating this relationship for any credit card debt (Model 1), logged total credit card debt (Model 2), any educational debt or student loans (Model 3), and logged total value of educational and student loan debt (Model 4). All models were based on the matched data and contained the same covariates present in Table 2.

\section{[Table 3]}




\section{[Table 4]}

The models in Table 3 show that the asset effects of coresidence were driven primarily by financial assets and pensions, but not by funds present in savings or checking accounts. Coresidence was associated with a $21.0 \%$ decrease in financial assets (Model 2) and a 34.7\% decrease in pension value, but it was not significantly associated with other asset outcomes. Thus, it appears as though supporting adult children limited a family's ability to build assets and save for retirement.

The models in Table 4, however, show that increases in both credit card and educational debt were responsible for the relationship between coresidence and debt. Households with adult children present held $33.6 \%$ more in credit card debt than households without adult children living there (Model 2). In addition, coresidential households were 15.9 percentage points more likely to hold educational debt and held more than 4 times as much in educational debt than noncoresidential households (Models 3 and 4). This indicates that many of the wealth effects of coresidence likely stemmed from the costs of post-secondary education in Canada, which are often taken on by both parents and their children.

\section{Discussion}

Although the models with this cross-sectional dataset are not causal, the results support a situation where coresidence and the continued support provided by parents to adult children destabilizes household resources and wealth across Canadian families. Even after accounting for key explanations of wealth inequality and differences between coresidential and non-coresidential households, households with adult children present held approximately $18 \%$ less in non-home assets and carried twice as much in non-home debt when compared to otherwise similar households without adult children present. These results stemmed from differences in financial 
assets, retirement savings, credit card debt, and educational loans. Coresidential households held $21 \%$ less in financial assets, $35 \%$ less in retirement savings, $34 \%$ more in credit card debt, and 4 times more educational debt than non-coresidential households.

These results extend conceptions of household and family structure to illustrate the complicated relationship between coresidence, support for adult children, assets, and debt. By highlighting the destabilizing wealth consequences associated with supporting and residing with adult children, this study demonstrates how financial hardship and economic insecurity can spread throughout a household. Net of family size, the presence of adult children in the household was associated with decreased assets, increased debt, and overall resource declines beyond the general demands of larger families. However, these disparities also likely stemmed from the costs of supporting adult children, as well as the greater obligations within parent-child relationships. With increasing economic insecurity and declining social safety nets, children require ever more support from their parents, which likely limits parental assets and can even motivate parents to take on more debt. Economies of scale are less helpful in such situations because the sharing of resources between parents and children is generally one directional -- downwards (Kahn et al. 2013).

In addition to showing the spread of financial hardship, this study addresses theories of economic insecurity, social capital, and the life course. Life course theories and perspectives grounded in economic insecurity both emphasize the importance of family and household relationships for understanding inequality, and they both stress how social and historical contexts influence trajectories of human development (Elder 1985; Elder et al. 2003). Parental obligations further enhance the normative embeddedness present within families (Furstenberg 2005). The trajectories and wellbeing of parents and children are tied, and these linkages continue even once children reach adulthood. For some parents, children are an investment; parental support now will 
be returned later. Increases in education debt mean that many adult children are obtaining degrees that will likely improve their later wealth and earnings. However, the ability of children to support parents later on will also depend on their financial situations and the broader economic context.

The results present further implications for policy within Canada and in other nations. First, they show that greater investment in social safety nets is needed if policymakers want to limit the financial hardship experienced by adult children from spreading to entire households. Canada still boasts a more generous welfare system than countries like the United States, but cuts to social assistance programs, such as Employment Insurance, throughout the 1990s and early 2000s, along with the continued declines of public investment in post-secondary education, have left many families struggling to make ends meet (Banting and Myles 2013; Luong 2010). This has had consequences for the wealth of parents and their adult children (Semyonov and LewinEpstein 2013). In this case, returning federal and provincial funding for higher education to earlier levels would greatly help to limit the burdens placed on families.

Second, the findings highlight outcomes associated with increasing student loan and credit card debt within Canada. Current wealth policies and programs, such as those encapsulated within Registered Retirement Savings Plans (RRSPs) and Tax Free Savings Accounts (TFSAs) tend to focus on asset development and benefit those with greater wealth. However, the results show that policy should also consider debt relief and payment, particularly within the area of student loan forgiveness. As debt ratios continue to rise, this issue is likely to become more problematic in the years to come (Chawla and Uppal 2012).

Despite its contributions, the research is still limited by the available measures and the cross-sectional nature of the data. Models could have been strengthened by accounting for the presence of adult children outside of the parental home within the models, but this measure was not present in the data. I was able to incorporate controls for age and marital status, two variables 
that are connected to parenthood and child age. Nevertheless, it is likely that some of the debt and asset effects of coresidence also stem from the support that parents provide to adult children more broadly, particularly for education purposes. In order to help account for this, models also included a control for whether households provided financial support for individuals living outside the household. Finally, future studies that include data on the specific situations of the adult children, why they moved home, and the length of periods of coresidence would also offer insight into heterogeneity among living situations.

In addition, even with the use of propensity score models that help to account for selection, the cross-sectional data allowed me to demonstrate only associations among variables, not causal order. Although propensity score matching models help to reduce confounding, they cannot truly recreate a randomized experiment, nor can they demonstrate causality (DuGoff et al. 2014). As a result, these data complicated the ability to fully determine whether coresidence with adult children decreased assets or whether families with fewer assets were more likely to live in coresidential households. It is likely that both situations influence the relationship between coresidence with adult children and wealth. Notably, however, coresidence was negatively associated with assets and positively associated with debt even after accounting for income and education, and in previous research parental wealth was not a strong predictor of coresidence (Hardie and Seltzer 2016). This indicates that even more advantaged families likely experience wealth declines when they support adult children living at home and elsewhere.

The study also shows that more research needs to be done in the areas of wealth inequality and economic insecurity. In recent years, researchers have begun to focus more on the debt and housing situations of young adults, but less research has examined how financial hardship can spread to other family members. In the case of educational debt, it seems likely that the debts of younger generations could be paid for, in part, by older generations who currently have greater 
resources. Household dynamics and intergenerational transfers are central to understanding broader aspects of wealth inequality and economic stability. Thus, studies that include information on different types of financial transfers among household and family members, as well as their wealth situations before and after coresidence, will help to provide additional insight into these processes. Longitudinal studies using household panel data, such as the U.S. Panel Study of Income Dynamics (PSID), that can show how family assets and debt change over time would be further address some of the limitations of this current study. This research would also be bolstered by qualitative studies that can shed light on family dynamics and the distribution of resource within households.

Overall, parent-child relationships and the support that is given within these relationships have long-term consequences for both generations (Elder 1985). With declining social safety nets and rising economic insecurity, more young adults require assistance from their parents to make the transition into adulthood in Canada. This support comes in many financial and non-financial forms, with housing being one of the most common types, especially among less-advantaged families. Although most young adults receive some financial aid from their parents, those who live at home tend to receive greater support (Schoeni and Ross 2005). When the continued burden of supporting young adults is placed on parents, however, declining assets and rising debt burdens become one of many potential negative consequences. 


\section{References}

Albertini, M., \& Kohli, M. (2012). The generational contract in the family: An analysis of transfer regimes in Europe. European Sociological Review, 29(4), 828-840. doi:10.1093/esr/jcs061

Amato, P.R., Booth, A., Johnson, D.R., \& Rogers, S.J. (2007). Alone together: How marriage in America is changing. Cambridge, MA: Harvard University Press.

Aquilino, W.S. (1996). The returning adult child and parental experience at midlife. In C.D. Ryff and M. Seltzer (Eds.), The parental experience at midlife (pp. 423-458). Chicago, IL: University of Chicago Press.

Banting, K., \& Myles, J. (2013). Inequality and the fading of redistributive politics. Vancouver, BC: UBC Press.

Bengtson, V. L. (2001). Beyond the nuclear family: The increasing importance of multigenerational bonds. Journal of Marriage and Family, 63(1), 1-16. doi:10.1111/j.1741-3737.2001.00001.x

Bianchi, S. M., Hotz, V. J., McGarry, K., \& Seltzer, J. A. (2007). Intergenerational ties: Alternative theories, empirical findings and trends, and remaining challenges (Report No. CCPR-024-06). Retrieved from California Center for Population Research On-Line Working Paper Series http://escholarship.org/uc/item/1g93v4kk.

Bourdieu, P. (1986). The forms of capital. In J. G. Richardon (Ed.), Handbook of theory and research for the sociology of education (pp. 241-258). New York, NY: Greenwood Press

Brzozowski, M., Gervais, M., Klein, P., \& Suzuki, M. (2010). Consumption, income, and wealth inequality in Canada. Review of Economic Dynamics, 13(1), 52-75. doi:

10.1016/j.red.2009.10.006

Cancian, M., \& Haskins, R. (2014). Changes in family composition: Implications for income, poverty, and public policy. The ANNALS of the American Academy of Political and Social 
Science 654(1): 31-47. doi:10.1177/0002716214525322

Cha, K.W., Weagley, R.O., \& Reynolds, L. (2005). Parental borrowing for dependent children's higher education. Journal of Family and Economic Issues, 26, 299-321. doi: $10.1007 / \mathrm{s} 10834-005-5900-\mathrm{y}$

Chawla, R. K., \& Uppal, S. (2012). Household debt in Canada. Perspectives on Labour and Income, 24(2), 1-15. Statistics Canada Catalogue no. 75-001-X.

Cherlin, A.J. (2010). Demographic trends in the United States: A review of research in the 2000s. Journal of Marriage and Family, 72(3), 403-419. doi: 10.1111/j.1741-3737.2010.00710.x

Choi, N.G. (2003). Coresidence between unmarried aging parents and their adult children: Who moved in with whom and why? Research on Aging, 25(4), 384-404. doi:10.1177/0164027503025004003

Cohen, P. N., \& Casper, L. M. (2002). In whose home? Multigenerational families in the United States, 1998-2000. Sociological Perspectives, 45(1), 1-20. doi:10.1525/sop.2002.45.1.1

Coleman, J. S. (1988). Social capital and the creation of human capital. American Journal of Sociology 94: 95-121. Retrieved from http://www.jstor.org/stable/2780243

DuGoff, H. E., Schuler, M., \& Stuart, E.A. (2014). Generalizing observational study results: Applying propensity score methods to complex surveys. Health Research and Educational Trust, 49(1), 284-303. doi:10.1111/1475-6773.12090

Dwyer, R.E., McCloud, L., \& Hodson, R. (2011). Youth debt, mastery, and self-esteem: Classstratified effects of indebtedness on self-concept. Social Science Research, 40(3), 727-41. doi:10.1016/j.ssresearch.2011.02.001

Elder, G.H., Jr. 1985. Life course dynamics: Trajectories and transitions, 1968-1980. Ithaca, NY: Cornell University Press.

Elder, G. H., Johnson, M. K., \& Crosnoe, R. (2003). The emergence and development of life 
course theory. In J. T. Mortimer and M. J. Shanahan (Eds.), Handbook of the life course (pp. 3-19). New York: Kluwer.

Fingerman, K., Kim, K., Davis, E., Furstenberg, F., Birditt, K., \& Zarit, S. (2015). "I'll give you the world": Socioeconomic differences in parental support of adult children. Journal of Marriage and Family, 77(4), 844-865. doi:10.1111/jomf.12204

Fingerman, K., Miller, L., Birditt, K., \& Zarit, S. (2009). Giving to the good and the needy: Parental support of grown children. Journal of Marriage and Family, 71(5), 1220-1233. doi:10.1111/j.1741-3737.2009.00665.x

Folbre, N. (2012). For love and money: Care provision in the United States. New York: Russell Sage.

Fortin, N., Green, D.A., Lemieux, T., Milligan, K., \& Riddell, W. C. (2012). Canadian inequality: Recent developments and policy options. Canadian Public Policy, 38(2), 121-45. doi:10.3138/cpp.38.2.121.

Fry, R., \& Passel, J. S. (2014). In post-recession era, young adults drive continuing rise in multigenerational living. Washington, D.C.: Pew Research Center's Social and Demographic Trends project, July.

Furstenberg, F.F. (2010). On a new schedule: Transitions to adulthood and family change. Future of Children, 20(1), 67-87. doi:10.1353/foc.0.0038

Furstenberg, F. F. (2005). Banking on families: How families generate and distribute social capital. Journal of Marriage and Family, 67(4), 809-821. doi:10.1111/j.17413737.2005.00177.x

Glick, J. E., \& Van Hook, J. (2002). Parents' coresidence with adult children: Can immigration explain racial and ethnic variation? Journal of Marriage and Family, 64(1), 240-253. Retrieved from http://www.jstor.org/stable/3599791 
Goldscheider, F.K., Thornton, A., \& Yang, L. (2001). Helping out the kids: Expectations about parental support in young adulthood. Journal of Marriage and Family, 63(3), 727-740. doi:10.1111/j.1741-3737.2001.00727.x

Grinstein-Weiss, M., Yeo, Y. H., Zhan, M., \& Charles, P. (2008). Asset holding and net worth among households with children: Differences by household type. Children and Youth Services Review, 30(1), 62-78. doi:10.1016/j.childyouth.2007.06.005

Hacker, J. S. 2006. The great risk shift: The new economic insecurity and the decline of the American dream. Oxford University Press.

Hacker, J. S., Huber, G. A., Nichols, A., Rehm, P., Schlesinger, M., Valletta, R., \& Craig, S. (2014). The economic security index: A new measure for research and policy analysis. Review of Income and Wealth, 60(S1), S5-S32. doi:10.1111/roiw.12053

Hardie, J.H., \& Seltzer, J.A. (2016). Parent-child relationships and the transition to adulthood: A comparison of black, Hispanic, and white immigrant and native-born youth. Social Forces, 95(1), 321-353. doi:10.1093/sf/sow033

Ho, D., Imai, K., King, G., \& Stuart, E. 2011. MatchIt: Nonparametric preprocessing for parametric causal inference. Journal of Statistical Software, 42(8), 1-28. doi: 10.18637/jss.v042.i08

Houle, J.N. (2014). A generation indebted: Young adult debt across three cohorts. Social Problems, 61(3), 448-465. doi:10.1525/sp.2014.12110

Kahn, J. R., Goldschneider, F., \& García-Manglano, J. (2013). Growing parental economic power in parent-adult child households: Coresidence and financial dependency in the United States, 1960-2010. Demography, 50(4), 1449-1475. doi:10.1007/s13524-013-0196-2

Kalmijn, M. (2013). The educational gradient in marriage: A comparison of 25 European countries. Demography, 50(4), 1499-1520. doi:10.1007/s13524-013-0229-x 
Kalmijn, M. \& De Graaf, P.M. (2012). Life course changes of children and well-being of parents. Journal of Marriage and Family, 74(2), 269-280. doi:10.1111/j.1741- 3737.2012.00961.x

Kamo, Y. (2000). Racial and ethnic differences in extended family households. Sociological Perspectives, 43(2), 211-229. doi:10.2307/1389794

Keister, L. A. (2000). Wealth in America: Trends in wealth inequality. New York, NY: Cambridge University Press.

Keister, L. A., \& Moller, S. (2000). Wealth inequality in the United States. Annual Review of Sociology, 26, 63-81. Retrieved from http://www.jstor.org/stable/223437

Kornrich, S., \& Furstenberg, F. (2013). Investing in children: Changes in parental spending on children, 1972-2007. Demography, 50(1), 1-23. doi:10.1007/s13524-012-0146-4

Lafrance, A., \& LaRochelle-Côté, S. (2012). The evolution of wealth over the life cycle. Perspectives on Labor and Income, 24(3), 1-16. Statistics Canada Catalogue no. 75-001$\mathrm{X}$.

Lei, L., \& South, S.J. (2017). Racial and ethnic differences in leaving and returning to the parental home: The role of life course transitions, socioeconomic resources, and family connectivity. Demographic Research, 34, 109-142. doi:10.4054/DemRes.2016.34.4

Lersch, P.M. (2017). The marriage wealth premium revisited: Gender disparities and withinindividual changes in personal wealth in Germany. Demography, 54(3), 961-983. doi:10.1007/s13524-017-0572-4

Luong, M. (2010). The financial impact of student loans. Perspectives on Labor and Income, 11(1), 5-18. Statistics Canada Catalogue no. 75-001-X.

Lupton, J. P., \& Smith, J. P. (2003). Marriage, assets, and savings. In S.A. Grossbard-Shechtman (Ed.), Marriage and the economy: Theory and evidence from advanced industrial societies (pp. 129-152). New York, NY: Cambridge University Press. 
Lusardi, A., Schneider, D., \& Tufano, P. (2011). Financially fragile households: Evidence and implications. National Bureau of Economic Research Working Paper Series No. 17072, 2011. Retrieved from http://www.nber.org/papers/w17072

MacDonald, B.J., Moore, K.D., Chen, H., \& Brown, R.L. (2011). The Canadian National Retirement Risk Index: Employing Statistics Canada's LifePaths to measure the financial security of future Canadian seniors. Canadian Public Policy, 37, S73-S94. doi:10.3138/cpp.37.suppl.s73

Macmillan, R., \& Copher, R. (2005). Families in the life course: Interdependency of roles, role configurations, and pathways. Journal of Marriage and Family, 67(4), 858-879. doi:10.1111/j.1741-3737.2005.00180.x

Maroto, M. (2017). When the kids live at home: Coresidence, parental assets, and economic insecurity. Journal of Marriage and Family, 79(4), 1041-1059. doi:10.1111/jomf.12407

Maroto, M. L. (2016). Fifteen years of wealth disparities in Canada: New trends or simply the status quo? Canadian Public Policy, 42(2), 152-167. doi:10.3138/cpp.2015-040

Maroto, M. (2015). Pathways into bankruptcy: Accumulating disadvantage and the consequences of adverse life events. Sociological Inquiry, 85(2), 183-216. doi:10.1111/soin.12073

Maroto, M. \& Aylsworth, L. (2017). Assessing the relationship between gender, household structure, and net worth in the United States. Journal of Family and Economic Issues, 38(4), 556-571. doi:10.1007/s10834-017-9521-z

Maroto, M. \& Aylsworth, L. (2016). Catching up or falling behind? Continuing wealth disparities for immigrants to Canada by region of origin and cohort. Canadian Review of Sociology, 53(4), 374-408. doi:10.1111/cars.12124.

McCall, L., \& Percheski, C. (2010). Income inequality: New trends and research directions. Annual Review of Sociology, 36, 329-347. doi:10.1146/annurev.soc.012809.102541 
McLanahan, S., \& Percheski, C. (2008). Family structure and the reproduction of inequalities. Annual Review of Sociology, 34, 257-276. doi:10.1146/annurev.soc.34.040507.134549

Messacar, D., \& Morissette, R. (2015). Employer pensions and the wealth of Canadian families. Statistics Canada, Insights on Canadian Society, Catalogue no. 75-006-X.

Milan, A. (2016). Diversity of young adults living with their parents. Statistics Canada, Insights on Canadian Society, Catalogue no. 75-006-X.

Morgan, S. L., \& Winship, C. (2007). Counterfactuals and causal inference: Methods and principles for social research. Cambridge University Press.

Osberg, L., \& Sharpe, A. (2014). Measuring economic insecurity in rich and poor nations. Review of Income and Wealth, 60, S53-S76. doi:10.1111/roiw.12114

Ozawa, M. N., \& Lee, Y. (2006). The net worth of female-headed households: A comparison to other types of households. Family Relations, 55(1), 132-145. doi:10.1111/j.17413729.2006.00362.x

Pilkauskas, N. V., Garfinkel, I., \& McLanahan, S. S. (2014). The prevalence and economic value of doubling up. Demography, 51(5), 1667-1676. doi:10.1007/s13524-014-0327-4

Portes, A. (1998). Social capital: its origins and applications in modern sociology. Annual Review of Sociology, 24, 1-24. doi:10.1146/annurev.soc.24.1.1

Rauscher, E. 2016. Passing it on: Parent-to-adult child financial transfers for school and socioeconomic attainment. RSF Journal, 2(6), 172-196. doi:10.7758/RSF.2016.2.6.09

Rosenbaum, P., \& Rubin, D. (1983). The central role of the propensity score in observational studies for causal effects. Biometrika, 70, 41-55. doi:10.1093/biomet/70.1.41

Ruggles, S. (2007). The decline of intergenerational coresidence in the United States, 1850 to 2000. American Sociological Review, 72(6), 964-989. doi:10.1177/000312240707200606 Sandberg-Thoma, S.E., Snyder, A.R., \& Jany, B.J. (2015). Exiting and returning to the parental 
home for boomerang kids. Journal of Marriage and Family, 77(3), 806-818. doi:10.1111/jomf.12183

Schmidt, L., \& Sevak, P. (2006). Gender, marriage, and asset accumulation in the United States. Feminist Economics, 12(1-2), 139-166. doi:10.1080/13545700500508445

Schoeni, R. F., \& Ross, K. E. (2005). Material assistance from families during the transition to adulthood. In R. A. Settersten, Jr., F. F. Furstenberg, Jr., and R. G. Rumbaut (Eds.), On the frontier of adulthood (pp. 396-416). Chicago, IL: University of Chicago Press.

Seltzer, J. A., \& Bianchi, S. M. (2013). Demographic change and parent-child relationships in adulthood. Annual Review of Sociology, 39, 275-290. doi:10.1146/annurev-soc-071312145602

Semyonov, M., \& Lewin-Epstein, N. (2013). Ways to richness: Determination of household wealth in 16 countries. European Sociological Review, 29(6), 1134-1148. doi:10.1093/esr/jct001

Settersten, R.A. Jr., \& Ray, B. (2010). What's going on with young people today? The long and twisting path to adulthood. Future of Children, 20(1), 19-41. doi:10.1353/foc.0.0044

Smits, A., van Gaalen, R.I., \& Mulder, C.H. (2010). Parent-child coresidence: Who moves in with whom and for whose needs? Journal of Marriage and Family, 72(4), 1022- 1033. doi:10.1111/j.1741-3737.2010.00746.x

South, S. J., \& Lei, L. (2015). Failures-to-launch and boomerang kids: Contemporary determinants of leaving and returning to the parental home. Social Forces, 94(2), 863-90. doi:10.1093/sf/sov064

Spilerman, S. (2000). Wealth and stratification processes. Annual Review of Sociology, 26, 497524. Retrieved from http://www.jstor.org/stable/223454

Statistics Canada. (2017). Table 206-0011 - Market income, government transfers, total income, 
income tax and after-tax income, by economic family type, Canada, provinces and selected census metropolitan areas (CMAs), annual. Retrieved from http://www5.statcan.gc.ca/cansim/a26?lang=eng\&id=2060011.

Statistics Canada. (2016). Percentage of young adults aged 20 to 24 and 25 to 29 living in the parental home, Canada, 1981 to 2011. Retrieved from http://www12.statcan.gc.ca/censusrecensement/2011/as-sa/98-312-x/2011003/fig/desc/desc3_3-1-eng.cfm.

Statistics Canada. (2015). Survey of Financial Security, 2012: Public Use Microdata user guide. Ottawa, Ontario: Statistics Canada. Income Statistics Division, Data Liberation Initiative. Statistics Canada. (2013). Education in Canada: Attainment, field of study and location of study, National Household Survey, 2011. Catalogue no. 99-012-X2011001.

Steele, F., Clarke, P., \& Washbrook, E. (2013). Modeling household decisions using longitudinal data from household panel surveys, with applications to residential mobility. Sociological Methodology, 43(1), 220-271. doi:10.1177/0081175013479352

Sullivan, T. A., Warren, W., \& Westbrook, J. L. (2000). The fragile middle class: Americans in debt. Yale University Press.

Swartz, T. T. (2009). Intergenerational family relations in adulthood: Patterns, variations, and implications in the contemporary United States. Annual Review of Sociology, 35, 191-212. doi:10.1146/annurev.soc.34.040507.134615

Swartz, T.T. (2008). Family capital and the invisible transfer of privilege: Intergenerational support and social class in early adulthood. New Directions for Child and Adolescent Development, 119, 11-24. doi:10.1002/cd.206

Swartz, T. T., Kim, M., Uno, M., Mortimer, J., \& Bengtson O'Brien, K. (2011). Safety nets and scaffolds: Parental support in the transition to adulthood. Journal of Marriage and Family, 73(2), 414-429. doi:10.1111/j.1741-3737.2010.00815.x 
Western, B., Bloome, D., Sosnaud, B., \& Tach, L. (2012). Economic insecurity and social stratification. Annual Review of Sociology, 38, 341-359. doi:10.1146/annurev-soc-07181114543

Wiemers, E. E. (2014). The effect of unemployment on household composition and doubling up. Demography, 51(6), 2155-2178. doi:10.1007/s13524-014-0347-0

Wooldridge, J. M. (2009). Introductory econometrics: A modern approach. 4th edition.

Cincinnati, OH: South-Western College Publishing.

Yelowitz A. (2007). Young adults leaving the nest: The role of the cost of living.” In Danziger S., and Rouse C.E. (Eds.), The Price of Independence: The Economics of Early Adulthood, (pp. 170-207). New York, NY: Russell Sage Foundation.

Zagorsky, J. L. (2005). Marriage and divorce's impact on wealth. Journal of Sociology, 41(4), 406-424. doi:10.1177/1440783305058478

Zanutto, E. L. (2006). A comparison of propensity score and linear regression analysis of complex survey data. Journal of Data Science, 4, 67-91. 
Table 1 Descriptive Statistics for the Survey of Financial Security (SFS), 1999-2012

\begin{tabular}{|c|c|c|}
\hline & Estimate & SE \\
\hline Mean non-home assets & 337,900 & 5,900 \\
\hline Any financial assets & 91.6 & 0.25 \\
\hline Mean financial assets & 56,700 & 1,700 \\
\hline Any accounts & 88.6 & 0.28 \\
\hline Mean savings and checking accounts & 10,800 & 200 \\
\hline Any pensions & 70.7 & 0.41 \\
\hline Mean pensions & 150300 & 2200 \\
\hline Mean non-home debt & 25,700 & 700 \\
\hline Any credit card debt & 63.1 & 0.43 \\
\hline Mean credit card debt & 1,900 & 100 \\
\hline Any educational loans & 12.1 & 0.32 \\
\hline Mean education debt & 1,800 & 100 \\
\hline Any adult children over age 18 present & 15.5 & 0.3 \\
\hline \multicolumn{3}{|l|}{ Adult children by age } \\
\hline Adult child age $18-25$ present & 10.6 & 0.25 \\
\hline Adult child age $26+$ present & 4.9 & 0.18 \\
\hline Age (R) & 48.7 & 0.14 \\
\hline \multicolumn{3}{|l|}{ Household type } \\
\hline Two adults, partners & 60.2 & 0.45 \\
\hline Single male adult & 18.2 & 0.37 \\
\hline Single female adult & 21.6 & 0.38 \\
\hline Mean household size & 2.4 & 0.01 \\
\hline Any children under 18 present & 28.4 & 0.39 \\
\hline Disability (R, SP, or Child) & 20.4 & 0.32 \\
\hline Adult landed immigrant & 17.4 & 0.33 \\
\hline \multicolumn{3}{|l|}{ Education level (R) } \\
\hline HS diploma & 22.2 & 0.37 \\
\hline Less than a HS diploma & 21.4 & 0.35 \\
\hline Some college & 34.9 & 0.42 \\
\hline Bachelor's degree & 14.3 & 0.3 \\
\hline Beyond a Bachelor's degree & 7.2 & 0.21 \\
\hline Mean household wage and salary income & 58,800 & 560 \\
\hline Employed (R or SP) & 73 & 0.37 \\
\hline Retired (R or SP) & 18.7 & 0.32 \\
\hline Own home & 61.7 & 0.45 \\
\hline Save regularly / Budget & 47.3 & 0.43 \\
\hline Provided assistance to family outside household & 12.6 & 0.28 \\
\hline \multicolumn{3}{|l|}{ Region } \\
\hline Atlantic & 7.3 & 0.19 \\
\hline Quebec & 25 & 0.4 \\
\hline Ontario & 37.1 & 0.45 \\
\hline Prairies & 16.8 & 0.26 \\
\hline $\mathrm{BC}$ & 13.7 & 0.27 \\
\hline \multicolumn{3}{|l|}{ Size } \\
\hline Rural & 14.2 & 0.3 \\
\hline CA population $<30,000$ & 12.3 & 0.25 \\
\hline CA population 30,000 - 99,999 & 9.6 & 0.25 \\
\hline CMA population $100,000-499,999$ & 14.6 & 0.29 \\
\hline CMA population $500,000+$ & 49.2 & 0.43 \\
\hline
\end{tabular}

SOURCES: 1999-2012 Pooled SFS - 33,201 households

NOTES: ${ }^{1}$ All estimates include sample survey weights implemented using bootstrapped standard errors.

${ }^{2}$ All dollar values appear in 2012 Canadian dollars.

${ }^{3}$ Unit of analysis (cases) = households (restricted to households where respondent is 18 years or older).

Most variables refer to the household as a whole. However, certain demographic variables refer to the

respondent or the respondent's spouse or partner. "R" refers to the respondent. Respondent in most cases is also the primary earner in the household. "SP" refers to the respondent's spouse or partner (if present). 
Table 2 Doubly Robust Regression Results Predicting Logged Total Non-home Assets and Debt, SFS 1999-2012

\begin{tabular}{|c|c|c|c|c|c|c|}
\hline & \multicolumn{3}{|c|}{ Model 1 - Logged NH Assets } & \multicolumn{3}{|c|}{ Model 2 - Logged NH Debt } \\
\hline & $e^{b}-1$ & $\mathrm{~b}$ & SE & $e^{b}-1$ & $\mathrm{~b}$ & SE \\
\hline Intercept & & $10.046^{* * *}$ & $(.195)$ & & $4.592 * * *$ & $(.536)$ \\
\hline Any adult children over age 18 present & -.182 & $-.201 * * *$ & $(.045)$ & .953 & $.670^{* * *}$ & $(.143)$ \\
\hline Age & .053 & $.051^{* * *}$ & $(.004)$ & -.040 & $-.041 * * *$ & $(.010)$ \\
\hline Age Squared & -.001 & $-.001 * * *$ & $(.000)$ & -.002 & $-.002 * * *$ & $(.000)$ \\
\hline \multicolumn{7}{|l|}{ Household type (Ref: 2 adult partners) } \\
\hline Single male adult & -.163 & -.179 & $(.141)$ & .936 & .661 & $(.459)$ \\
\hline Single female adult & -.504 & $-.700 * * *$ & $(.127)$ & -.553 & $-.805^{*}$ & $(.326)$ \\
\hline Household size & .055 & $.054^{*}$ & $(.027)$ & .244 & $.219^{* *}$ & $(.075)$ \\
\hline Any children under age 18 present & -.059 & -.061 & $(.067)$ & .076 & .073 & $(.203)$ \\
\hline Household wage and salary income (logged) & .096 & $.091 * * *$ & $(.013)$ & .100 & $.095^{* *}$ & $(.033)$ \\
\hline Employed (R or SP) & .231 & $.208^{*}$ & $(.099)$ & 1.355 & $.857 * *$ & $(.275)$ \\
\hline \multicolumn{7}{|l|}{ Education (Ref: High school degree) } \\
\hline Less than HS degree & -.356 & $-.440 * * *$ & $(.085)$ & -.379 & $-.476^{*}$ & $(.231)$ \\
\hline Some college & .182 & $.167 * *$ & $(.054)$ & .262 & .232 & $(.176)$ \\
\hline Bachelor's degree & .869 & $.625^{* * *}$ & $(.065)$ & -.237 & -.270 & $(.235)$ \\
\hline Beyond Bachelor's degree & 1.073 & $.729 * * *$ & $(.081)$ & -.155 & -.168 & $(.289)$ \\
\hline Any disability (R, SP, or Child) & -.232 & $-.263 * * *$ & $(.055)$ & .482 & $.393 *$ & $(.156)$ \\
\hline Own home & 3.218 & $1.439 * * *$ & $(.072)$ & 1.985 & $1.094 * * *$ & $(.188)$ \\
\hline Have a budget & -.096 & $-.101 *$ & $(.043)$ & .598 & $.469^{* * *}$ & $(.135)$ \\
\hline Gave assistance & .346 & $.297 * * *$ & $(.060)$ & .531 & $.426^{*}$ & $(.188)$ \\
\hline Adult landed immigrant (R or SP) & -.457 & $-.611 * * *$ & $(.055)$ & -.523 & $-.740 * * *$ & $(.175)$ \\
\hline \multicolumn{7}{|l|}{ Region (Ref: Atlantic Provinces) } \\
\hline Quebec & .478 & $.391 * * *$ & $(.115)$ & -.496 & $-.685 *$ & $(.314)$ \\
\hline Ontario & .452 & $.373^{* * *}$ & $(.107)$ & -.471 & $-.636^{*}$ & $(.297)$ \\
\hline Prairies & .683 & $.521 * * *$ & $(.108)$ & -.460 & $-.617 *$ & $(.304)$ \\
\hline $\mathrm{BC}$ & .915 & $.650 * * *$ & $(.111)$ & -.470 & $-.635^{*}$ & $(.315)$ \\
\hline \multicolumn{7}{|l|}{ Size (Ref: Rural) } \\
\hline CA population $<30,000$ & .027 & .027 & $(.083)$ & -.345 & -.423 & $(.261)$ \\
\hline CA population $30,000-99,999$ & .183 & .168 & $(.087)$ & -.070 & -.072 & $(.263)$ \\
\hline CMA population $100,000-499,999$ & .129 & .121 & $(.084)$ & .040 & .039 & $(.245)$ \\
\hline CMA population $500,000+$ & .119 & .112 & $(.074)$ & -.134 & -.143 & $(.213)$ \\
\hline \multicolumn{7}{|l|}{ Year (Ref: 1999) } \\
\hline Year 2005 & -.005 & -.005 & $(.054)$ & .461 & $.379^{*}$ & $(.173)$ \\
\hline Year 2012 & .286 & $.251 * * *$ & $(.044)$ & 1.562 & $.941 * * *$ & $(.143)$ \\
\hline AIC & 17480 & & & 185490 & & \\
\hline Pseudo R-Squared & .416 & & & .145 & & \\
\hline \multicolumn{7}{|c|}{$\begin{array}{l}\text { SOURCE: } 1999-2012 \text { Pooled SFS, Models based for matched pairs data, } \mathrm{N}=5,022 \text { households with adult children present and 5,022 without adult } \\
\text { children present } \\
\text { NOTES: Generalized linear regression models predicting logged non-home assets and debt. Samples created via propensity score matching with } \\
\text { nearest neighbor matching. All dollar values appear in } 2012 \text { Canadian dollars. Continuous variables are mean centered. Standard errors account for } \\
\text { clustering. Models include sample survey weights. " } \mathrm{e}^{\mathrm{b}}-1 \text { " can be interpreted as a percent change in assets/debt associated with a one-unit change in } \\
\text { the predictor variable. }\end{array}$} \\
\hline
\end{tabular}


Table 3 Doubly Robust Regression Results Predicting Specific Asset Types, SFS 19992012

\begin{tabular}{|c|c|c|c|c|c|c|}
\hline & \multicolumn{3}{|c|}{ Model 1 - Any financial assets } & \multicolumn{3}{|c|}{ Model 2 - Logged total financial assets } \\
\hline & AME & $\mathrm{b}$ & SE & $\mathrm{e}^{\mathrm{b}}-1$ & $\mathrm{~b}$ & SE \\
\hline Intercept & & $1.258 * *$ & $(.438)$ & & $5.427 * * *$ & $(.390)$ \\
\hline Any adult children over age 18 present & -.009 & -.209 & $(.152)$ & -.210 & $-.236^{*}$ & $(.102)$ \\
\hline AIC & 4445 & & & 81120 & & \\
\hline \multirow[t]{3}{*}{ Pseudo R-Squared } & .083 & & & .196 & & \\
\hline & \multicolumn{3}{|c|}{ Model 3 - Any accounts } & \multicolumn{3}{|c|}{ Model 4 - Logged account value } \\
\hline & AME & $\mathrm{b}$ & SE & $\mathrm{e}^{\mathrm{b}}-1$ & $\mathrm{~b}$ & SE \\
\hline Intercept & & $1.264 * * *$ & $(.374)$ & & $4.962 * * *$ & $(.388)$ \\
\hline Any adult children over age 18 present & -.003 & -.040 & $(.119)$ & -.037 & -.038 & $(.097)$ \\
\hline $\mathrm{AIC}$ & 6140 & & & 80758 & & \\
\hline \multirow[t]{3}{*}{ Pseudo R-Squared } & .047 & & & .133 & & \\
\hline & \multicolumn{3}{|c|}{ Model 5 - Any pensions } & \multicolumn{3}{|c|}{ Model 6 - Logged pension value } \\
\hline & AME & $\mathrm{b}$ & SE & $\mathrm{e}^{\mathrm{b}}-1$ & $\mathrm{~b}$ & SE \\
\hline Intercept & & -.221 & $(.421)$ & & $5.732 * * *$ & $(.620)$ \\
\hline Any adult children over age 18 present & -.018 & -.189 & $(.118)$ & -.347 & $-.426 * *$ & $(.138)$ \\
\hline AIC & 7190 & & & 148833 & & \\
\hline Pseudo R-Squared & .247 & & & .335 & & \\
\hline \multicolumn{7}{|l|}{$* * * \mathrm{p}<.001, * * \mathrm{p}<.01, * \mathrm{p}<.05$} \\
\hline \multicolumn{7}{|c|}{$\begin{array}{l}\text { SOURCE: } 1999-2012 \text { Pooled SFS, Models based for matched pairs data, } \mathrm{N}=5,022 \text { households with adult children present and 5,022 } \\
\text { without adult children present } \\
\text { NOTES: Generalized linear regression models predicting (1.) any financial assets, (2.) logged total financial assets, (3.) any checking or } \\
\text { savings accounts, (4.) logged total value of checking and savings accounts, (5.) any pensions, and (6.) logged pension value. Samples } \\
\text { created via propensity score matching with nearest neighbor matching. All dollar values appear in } 2012 \text { Canadian dollars. Standard errors } \\
\text { account for clustering. Models include all covariates present in Table } 3 \text { and sample survey weights. "AME" refers to average marginal } \\
\text { effects, which can be interpreted as a percentage point change in the presence of assets/debt associated with a unit change in the predictor } \\
\text { variable. "e }-1 \text { " can be interpreted as a percent change in assets/debt associated with a one-unit change in the predictor variable. }\end{array}$} \\
\hline
\end{tabular}


Table 4 Doubly Robust Regression Results Predicting Specific Debt Types, SFS 19992012

\begin{tabular}{|c|c|c|c|c|c|c|}
\hline & \multicolumn{3}{|c|}{ Model 1 - Any credit card debt } & \multicolumn{3}{|c|}{ Model 2 - Logged total credit card debt } \\
\hline & AME & $\mathrm{b}$ & SE & $e^{\mathrm{b}}-1$ & $\mathrm{~b}$ & SE \\
\hline Intercept & & $-.973 * * *$ & $(.262)$ & & $1.926^{* * *}$ & $(.464)$ \\
\hline Any adult children over age 18 present & .033 & .137 & $(.072)$ & .336 & $.290 *$ & $(.133)$ \\
\hline AIC & 13021 & & & 152591 & & \\
\hline \multirow[t]{3}{*}{ Pseudo R-Squared } & .052 & & & .068 & & \\
\hline & \multicolumn{3}{|c|}{ Model 3 - Any education debt } & \multicolumn{3}{|c|}{ Model 4 - Logged total education debt } \\
\hline & AME & $\mathrm{b}$ & SE & $e^{b}-1$ & $\mathrm{~b}$ & SE \\
\hline Intercept & & $-3.529 * * *$ & $(.335)$ & & .433 & $(.319)$ \\
\hline Any adult children over age 18 present & .159 & $2.050 * * *$ & $(.145)$ & 3.344 & $1.469^{* * *}$ & $(.092)$ \\
\hline AIC & 6871 & & & 89505 & & \\
\hline Pseudo R-Squared & .156 & & & .107 & & \\
\hline \multicolumn{7}{|l|}{$* * * \mathrm{p}<.001, * * \mathrm{p}<.01, * \mathrm{p}<.05$} \\
\hline \multicolumn{7}{|c|}{$\begin{array}{l}\text { SOURCE: } 1999-2012 \text { Pooled SFS, Models based for matched pairs data, } \mathrm{N}=5,022 \text { households with adult children present and 5,022 } \\
\text { without adult children present } \\
\text { NOTES: Generalized linear regression models predicting (1.) any credit card debt, (2.) logged total credit card debt, (3.) any educational } \\
\text { debt, and (4.) logged total value of educational debt. Samples created via propensity score matching with nearest neighbor matching. All } \\
\text { dollar values appear in } 2012 \text { Canadian dollars. Standard errors account for clustering. Models include all covariates present in Table } 3 \text { and } \\
\text { sample survey weights. "AME" refers to average marginal effects, which can be interpreted as a percentage point change in the presence } \\
\text { of assets/debt associated with a unit change in the predictor variable. "e } \mathrm{e}^{\mathrm{b}}-1 \text { " can be interpreted as a percent change in assets/debt } \\
\text { associated with a one-unit change in the predictor variable. }\end{array}$} \\
\hline
\end{tabular}

